\title{
Rankings of Universities and Power in the Digital Age
}

\author{
Mario Alberto Velázquez Garcíaa , Lilian Ivetthe Salado Rodríguez ${ }^{b}$
}

\begin{abstract}
This paper will discuss one topic in the current debate on higher education: How power is exercised between universities? How do colleges determine what the best college is? What are the differences in the excersise of power in the digital age? The authors analyze one of the mechanisms of relationship and contact between different universities: the rankings. They will discuss the practices that allow certain values and organizations they are becoming central nodes between universities and the influences of the information and communication technologies in the measurement mechanisms. The authors seek to show the rankings serve as mechanisms to exercise power among universities. These measurements become a tool and justification in competition between universities for resources such as funding, prestige, and student demand. The analysis is based on the University of Mexico, the authors use the ranking of the best universities in Latin America and the best universities in Mexico.
\end{abstract}

\section{Keywords}

Technology, power, university, ranking, Mexico

Information and communication technologies (ICTs) such as computers and the internet are conceived by governments, such as the Mexican, as tools that allow them to end the inequalities in university educational systems in terms of quality, coverage, and opportunities. Among the objectives of the Plan Nacional de Desarrollo (National Development Plan) 2013-2018 of Mexico, it is to promote the development and use of new technologies in the educational system at all levels to support the inclusion of students in the knowledge society and expand their capacities for life ${ }^{1}$.

However, the distance between this government project and reality, in the case of Mexico, is wide and even shows contradictory results. In the country, access to higher education remains highly concentrated in the middle and upper strata of society (between $75 \%$ and $80 \%$ of graduates belonging to these levels), there is also an unequal territorial distribution of educational opportunities and significant correlation between parents' and children's education (Ornelas 2008). That is socio-economic conditions remain central to the aspiration to pursue and complete university studies. Differences in quality of the variety of universities, particularly among those located in urban and rural areas, continues to be present. Thus, while technological tools (computers,

\footnotetext{
anstituto Tecnológico Superior de Cajeme (Higher Technological Institute of Cajeme), México

bUniversidad Estatal de Sonora (Sonora State University), México

\section{Correspondent Author:}

Lilian Ivetthe Salado Rodríguez, Ley Federal del Trabajo S/N Col. Apolo, Zip Code: 83100, Hermosillo, Sonora, México

E-mail: lilian.salado@ues.mx
} 
telephones, internet, lab equipment, etc.) are becoming more critical for the development of the core activities of current universities day by day, their use measured as recognition, prestige, degree, public resources, employment of graduates, among others, continues to show results which are differentiated by strata.

In Mexico, there are 180 institutions of higher education, the greatest expansion in the number of these institutions occurred in the period of 2006-2011. The university educational system in this country has experienced, since the end of last century and the first decade of the twenty-first century, a steady growth in the number of young people who undertake a university degree. During this period, demand was nearly two and a half million and grew to a million more, that is, three and a half million for the 2012-2013 cycle. This growth is reflected in an increase in educational coverage, which advanced from giving coverage to $25 \%$ of young people in 2006 , to reaching $35 \%$ in 2012. These figures place Mexico among the countries with the highest coverage in Latin America, however, results are still low when compared with coverage levels of countries like the US where coverage reaches $70 \%$ of young people (Clark 2002; Tuirán 2012).

This paper addresses one of the central issues in contemporary discussion on higher education: How is power exercised in universities under the so-called "digital age", in this case, the relationship between the different university centers. More specifically, what are the mechanisms that allow certain values, practices, and organizations to become the hubs of relations between universities and the influence of ICTs in these relationships. Very specifically, different rankings (positions and items that are evaluated) will be revised to show that these types of measurements function as mechanisms for the exercising of power between universities, seeking to influence competition for valued resources in this organizational framework such as funding, prestige, and student demand.

For this analysis, the authors will use the theoretical proposal of Manuel Castells (2009; 2004). This author developed an explanation of the functioning of contemporary societies: the network societies. He proposes that the development of ICT generated a significant transformation in social relations, both in existing ones and the creation of new ones. The network society does not only have changes in the economic and communicative areas, but also in political areas (Castells 2004). For Castell, modern times are undergoing a major change in the functioning of power ${ }^{2}$, this is no longer located only within nation-states, but in global interactions of different actors. This does not mean that nation-states lose their function or importance, but these territorial entities and organizations are one within the various points (nodes) of global power: The power is now located on the networks (Castells 2009). New forms of control relate to information flows and inclusion, exclusion (or a type of these) within networks. This does not mean that the old forms of domination and inequality will disappear, but that they remain, overlap and/or are complemented by the new ones (Castells 2009; Castells 2010).

In Castells' proposed theory, power is an attribute present in all social relations. It is defined as the ability to asymmetrically influence decisions of other social actors (Castells 2009). In this case, it would mean that a university or a set of them has the ability to decide sets of behavior toward other universities. To analyze this way of exercising power in the network society, university rankings will be used as an empirical benchmark. Namely, the lists that through a series of indicators give each educational institution a position within a scale, classifying them from best to worst. The authors will use the university ranking, Webometrics, the Academic Ranking of World Universities, three national rankings and one in Latin America. The authors assume that rankings are a reflection of the global functioning of power in the network society, where a set of values defined outside the logic and practices of companies and organizations, 
in this case of universities in Mexico, impose practices and determine the way in which the rest of the groups categorizes them in strata.

In a first section, the authors will provide conceptual elements of the theory of Castells on power in the digital age. With them, the authors seek to understand which are these transformations that have occurred in the operation of the relations between the different organizations on a global scale. Castell's proposal allows us to understand that the totality of the culture, economy, and contemporary politics exerts a power over all kinds of behaviors in organizations such as universities. On a second section, they will carry out an analysis on the role that the rankings have in the network society; a sociology of the rankings, focusing mainly on their role within the power of the global society. Then, they will analyze the measurement of the items evaluated and the results that these rankings yield.

\section{POWER IN THE DIGITAL AGE: THE CASE OF UNIVERSITIES}

Capitalism has undergone a radical transformation moving from a business model to a model of information development (Webster 1995). The power is now built and flows in a global manner through networks (the global network society); the creation of knowledge and information is the new pillars of development. This does not mean that manual labor and the accumulation of goods lose value, what this change wants to represent is that the factors determining economic growth have changed. The network society is defined by Castells as “... one whose structure is composed of networks activated by digital information and communication technologies networks based on microelectronics..." (Castells 2009: $51)$.

A key element to consider is how a network assigns value to the activities of its components. That is how to determine which behaviors are more important than others. In this regard, Castells suggests that when it comes to value, the network society has not changed from the previous: "... value is what the dominant institutions of society decide it to be... (emphasis added)" (Castells 2009: 54). This is especially important in the case of institutions, because it means that the distribution of legitimacy (prestige in this case) to universities is not fixed externally, but it is constructed from internal elements to the network, i.e., to the same universities. Hence, the high valuation that is assigned to a given university for having a high number of scholars with international recognition versus a small state university that achieves high levels of social mobility within the community is an appointment of prestige from power.

The knowledge that was traditionally created, distributed, and reproduced in universities has become an essential part of our lives, because we are increasingly dependent on it and in this new paradigm, those who hold that property will be those who will have the power in their hands. This has major implications for education because as stated by UNESCO (United Nations Educational, Scientific, and Cultural Organization) (2005), it will play a vital role in the collaboration, application, and creation of the same or at least that is what is expected. However, higher education is faced with serious problems, mainly because it has not changed as quickly as the other sectors of the general social system and the social functions of the university have exceeded the generation and reproduction of knowledge. This brings us to reflect on what is really happening in the various establishments of tertiary education.

In this reconfiguration of power, there are what Castells calls as centers, this is organizations, groups, or individuals that concentrate relevant information and where it is processed more efficiently. The centers are also transcendent, because it is in them that the network generates some of its major resources to achieve its goals (Castells 2009: 20). In the case of 
universities, these centers are those schools that assemble some of the key resources for the development of substantive activities for such organizations such as large libraries, high capacity computers, laboratories with highly specialized equipment, and researchers with great recognition, among others. In this regard, it is noteworthy that a contribution of Castells to the study of networks, is to note that these have in their central operation of the pursuit of power. Although their main component is the flow of communication, it does not mean that this is their only interest, the various nodes within the network seek to impose within this communication, generating an influence on the behavior of others. That is exercising power (Castells 2009). This exercise of dominance occurs through a basic binary code: inclusion/exclusion. Under this principle, they build their network connections and ignore some nodes considered outside the guidelines of such network.

The allocation of goals and rules within a network are the programs, these are made of codes that include validation of behavior and criteria for deciding what actions, interactions, or individuals are successful and which are not (Castells 2009: 20). In the case of universities, this creation of programs is not only an attribute, reason why, even though operating under levels of relative autonomy, universities (particularly the large current universities) are subject to asymmetric convergences forcing them to redefine their goals in reference to state, companies, or (the church in the case of universities founded by a religious order) various social organizations interests and guidelines. University programs do not only include internal rules themselves (labor standards, academic incentives, scholarships, etc.), but also external standards [in the case of Mexico, the National Council of Science and Technology (Consejo Nacional de Ciencia y Tecnología - CONACYT)] are great builder of programs by setting criteria for quality, performance, and resource allocation [National
System of Researchers (Sistema Nacional de Investigadores- $\mathrm{SNI}$ ), research resources, evaluation of the same universities, master, and doctor degrees].

Cooperation and competition are two behaviors that occur between the nodes of a network. These two forms of interaction are conditioned by the ability of networks to communicate with each other through codes (Castells 2009). In this sense, science generally tends to be presented as the work of isolated individuals who propose ideas that allow the development of theories, methodologies, and discoveries. However, various studies regarding the way a kind of knowledge is taken as valid by the scientific community, have shown that the theories, methodologies, and specific tools (laboratories, methodological instruments) arise from an interactive cooperation and an exchange of practices. In science, as in other fields of society, there is a competition generated for the credibility of speeches, generating consensus on what is true and what is not. In other words, knowledge, like all human activity, does not escape from being founded on power structures.

For Castells, another fundamental change in the configuration of power in the information age is in the configuration of organizations. We are moving from the modern era that Weber characterized by its growing bureaucracy to a process of de-bureaucratization; large administrative apparatuses are more frequently replaced by more flexible networks even in large corporations (Webster 1995). This is definitely a challenge and a problem for universities, especially those from countries such as Mexico where large bureaucracies exist in the functioning of these educational institutions.

Universities are key institutions of the modern era. This prevails until today even though there has been a transformation in the functions socially assigned to these organizations since their inception in the Middle Age (Dubet 2004). Universities are not only spaces for the training of individuals in some of the core skills for work (in this sense, the institution that certifies the 
acquisition of knowledge), but also creators and reproducers of culture, source of formation of political cadres as well as a productive business. Nonetheless, as noted by Castells (2009), universities play another key role. They are one of the cores of power flow in two of the key elements of modern societies: communication and technology.

Universities are institutions related to the creation of technological advances in various fields, as well as creating some languages (computer software, theories, certifications, etc.) by which social institutions and sectors communicate. This power to create new languages for communication allows universities to influence the behavior of other organizations (businesses, governments, civil society, etc.) (Castells 2009). This ability to influence does not represent an attribute specifically assignable to a group of individuals or organizations per se, but is a relational quality. This attribute, being a relational capacity, is distributed across the social spectrum though not in a uniform manner. There are nodes, in this case, universities, which concentrate capabilities (such as creating languages) or the development of technologies allowing them to influence a wide range of institutions. In other words, in the digital age, the capacity of control (power) of contemporary universities is not related to possession of assets (buildings, laboratories, and libraries), but to the ability to influence the information flows (Castells 2004).

In the case of science, power has two components: institutions as a durable set of practices and ideas that are organized around a praxis and that largely explain everyday experience. On the other hand, the networks which can be defined as the relationship between individuals and organizations. In the case of science, networks make sense in thinking them in how they connect (or exclude) certain groups of the institutions of dominance, thereby distributing power and transforming it into institutionalized agreements between organizations. It is important to mention the existence of a kind of international division of labor, so that a few countries specialize in the production of high-value and creation of knowledge and information (Japan, US, and Germany), another group located in the massive production of derived products (China, India, and Taiwan), a third group that produces commodities (oil producers, grain, and food), and finally, a fourth group will generate redundant assets (countries in extreme poverty) (Webster 1995). This division is reproduced in universities so that only a group of higher education institutions produces new knowledge, while the rest will reproduce it. The same division occurs within each country where there are institutions that have a predominance over the rest. This will be crucial for the issue we seek to analyze, because this predominance of certain centers has a very clearly defined spatial distribution in large cities, situation which as Castells has demonstrated, is not transformed by the existence of "free" communication networks, on the contrary, it consolidates old practices of power.

These theoretical elements of Castells to understand the power will allow us to analyze how the same is reproduced within the university context. The concept of power allows us to understand the causes and consequences of technological change for the development and teaching of the universities in Mexico.

\section{CODES AND UNIVERSITY RANKINGS: POWER IN THE GLOBAL SOCIETY}

Until the early modern era, the basic programs of universities, their main objectives were related to the production and accumulation of knowledge. This logic of operation allowed the autonomous and independent development of different branches of knowledge. Universities codes were led to the accumulation of studies and theories in both the form of archives and libraries, and in the presence of individuals who have also made a significant accumulation of knowledge 
(the figure of the "classic" scholars). In this sense, competition between universities is produced from the ability of each to have more or better libraries, more scholars, students, programs, and so on. The age of a university was a mark of distinction, because its longevity meant a greater accumulation of tangible (books, laboratories, and specialists) and intangible (discoveries, experience, and knowledge schools) knowledge. Therefore, those universities with less recognition were tendentiously new, small, and poor. In a worldwide ranking, a general classification was generated where the old universities of Europe (the first universities in the world) occupied a predominant role. All new universities sought to imitate their programs and adopt their codes.

As we have seen with Castells, the network society means a transformation of values. ICT take a central role in the transformations of industrial processes, the discovery of new materials and the development of software: It is the era of knowledge and network communication. This produces necessarily a restructuring of the codes and programs that guide the functioning of institutions directly related to the production of new knowledge such as universities.

Rankings are not a new phenomenon but an idea that arose more than a century ago in the United States (Martínez Rizo 2011) and whose proliferation has accelerated since the intervention of international organizations like the World Bank (WB), the Organization for Economic Cooperation and Development (OECD), among others, in different social spheres result of the increasing cooperation between the states and their relationships framed in the context of globalization. The following will list some of the characteristics and social functions of the rankings:

(1) Rankings are, in the end, a list of items that share a common trait, in this case that they are universities, and they are classified by a number of criteria from highest to lowest. This list constitutes a speech. Which is of central importance to the network society since the general principle of operation of this communication network is the inclusion and exclusion. Such lists are then, a mechanism to decide which organizations are placed into certain categories or not; in this case which are the best universities and which are not;

(2) Rankings are a mechanism for the imposition of programs to the rest of the nodes on the network. Behavior (codes) that are valued within the rankings are those who seek to be imposed as the most productive or rational. But, why it would be necessary for a university to reproduce programs and codes that move away from its daily behavior? The importance of being part of the rankings is not only about the possible prestige it provides, but it has specific effects on universities. Rankings influence the action of those organizations and individuals who have to make decisions about universities, whether in choosing them, finance, or value them: government bodies that provide resources, social foundations that make donations, companies that invest in research, students selecting the place to study, the media and society in general. In the new role that universities have as businesses, rankings serve as communication protocols that determine what place each organization has in that market;

(3) Rankings are not neutral classifications but rather a practice of power of the nodes of the network of universities worldwide. Rankings are one of the scenarios where this "objective" competition among universities occurs. These lists contain the value that certain groups assign to certain programs and codes. The values in rankings are not defined by consensus, but are imposed by the dominant institutions. As Castells (2009) explains, in the network society, this valuation is built from the central nodes which dominate the universities from the rest of the world, that is outside the criteria or forms of action that universities such as Mexican's have by themselves which need to adapt to access these new values or 
practices. For example, a ranking can be built considering as fundamental parameters of the number of publications in international journals, financed research projects, number of researchers belonging to a national research system, number of international awards received by members of the university, etcetera. These criteria consider some of the key areas in the work of a university, but have been defined from the priorities in the operation of universities in other countries. In the case of Mexico, we can assume the existence of another series of activities developed by a university that hold a similar importance to: the number of poor people registered, the number of community projects undertaken by the university, the number of students belonging to an ethnic group, among others;

(4) The power exercised in the network society does not mean the disappearance of old forms of control and inequality, by contrast, they will overwrite the previous ones. In the case of universities, rankings not only reflect the differences on the management of ICT and international networks, but the historical differences in the infrastructure, budgets, and resources among different universities. In this sense, rankings cover the old inequalities from the illusion that they are measuring agents with the same resources to compete. Is it true that American universities are at the top because they have the best staff or simply because they have the resources to hire these people in the rest of the world?

(5) In the case of Mexico, inequality among agents evaluated in rankings reflects spatial inequalities. The resources that historically have had different entities to fund their universities, the centralization of spending and accumulation of an uneven growth are clearly visible in these lists. Rankings are not then an objective and serious analysis of the functioning of universities, but a standard set from the power of certain groups seeking to justify their supremacy with data.

\section{RANKINGS OVER MEXICAN UNIVERSITIES}

There is a number of global, national, or Latin American rankings over universities. After reviewing a group of them, the authors will present a series of observations regarding the role that these have as narratives in the power relations among universities:

(1) Rankings apply different weightings to decide which are the most significant criteria to measure Mexican universities and those from the rest of the world. When comparing the rankings, a first result is that they are all clearly measuring with different criteria, there is neither the interest nor the need to generate minimum agreements on which are the most important characteristics that define the work of universities. Although, there is agreement on using values such as research or teaching, the weight and significance of these categories varies widely;

(a) A national ranking is presented by the newspaper El Financiero where they presented "The Best Universities in Mexico". The valuation criteria were: teaching quality $(30 \%)$, research index $(20 \%)$, employability (20\%), post-graduate offer $(15 \%)$, and international prestige (15\%). The 10 places, from first to 10th were: Universidad Nacional Autónoma de México (UNAM), Instituto Politécnico Nacional (IPN), Sistema Instituto Tecnológico y de Estudios Superiores de Monterrey (ITESM), Universidad Autónoma Metropolitana (UAM), Universidad Autónoma de Nuevo León (UANL), Universidad de Guadalajara (U de G), El Colegio de México (Colmex), Instituto Tecnológico Autónomo de México (ITAM), Universidad de las Américas Puebla (UDLAP), and Sistema Universidad Iberoamericana (Ibero) (El Financiero 2014);

(b) América Económica magazine presented the 2015 ranking Universidades de México using the following methodology: teaching quality $(30 \%)$, research $(20 \%)$, reputation among employers $(20 \%)$, post-graduate educational offer $(15 \%)$, internacional prestige $(10 \%)$, and accrediting (5\%). The 10 places, 
from first to 10th were: UNAM, ITESM, IPN, UAM, Colmex, UANL, UDLAP, U de G, ITAM, and Ibero;

(c) The ranking of the "Best Universities in Latin America", presented in Forbes Magazine (Spanish edition) used the following values: academic reputation $(30 \%)$, reputation with employers $(20 \%)$, faculty/students ratio $(10 \%)$, quotes per articles $(10 \%)$, research by faculty $(10 \%)$, staff with $\mathrm{PhDs}(10 \%)$, impact on the internet (10\%) (Forbes 2015). This measurement is made from 300 universities in 18 Latin American countries, considering 46 universities of Mexico. The better positioned universities are Tecnologico de Estudios Superiores de Monterrey (7th) and the National Autonomous University of Mexico (8th);

(d) The "World Ranking of Universities on the Web"3 used the following values: 1. development of web indicators applied to scenarios of research, innovation and development; 2. quantitative studies on scientific communication through electronic journals and repositories, and the impact of Open Access initiatives; 3. development of indicators on content type in the information society; 4. display of indicators and social media on the web with friendly, dynamic, and interactive graphic interfaces; 5. design and evaluation of documental analysis techniques of web resources; 6 . gender studies applied to academic activity on the web; 7. development of applied cybermetrics techniques based on the positioning of web sites in search engines; and 8. information consumption analysis through web $\log$ file data mining. Due to the application of the above criteria, the results of this ranking yield the following information. Worldwide, the top 10 universities are located in the United States (see Table 1), in Latin America; they are concentrated in Brazil (7), Mexico (1), Chile (1), and Argentina (1) (see Table 2) and finally for the case of Mexico, the top ranked universities are located in the following states: Distrito Federal (4), Nuevo Leon (2), Estado de Mexico (1), Jalisco (1), Sonora (1), and Michoacan (1) (see Table 3);

(e) The British Quacquarelli Symonds (QS) Company University Ranking. The valuation system of this ranking is designed to allow institutions to appear in it regardless of their size, form, and mission. The system provides an international standard for comparison of any participating institution and the university is qualified based on eight criteria: 1 . research, with criteria such as number of papers published, citations, and awards; 2. employability, surveys to employers, graduates, and average wages; 3 . teaching, rating based on student surveys; 4 . infrastructure, medical support, and student societies; 5. internationalization, proportion of foreign students and staff (in exchange); 6. Innovation; 7. commitment, contributions to the community; and 8 . prestige of the institution on specialized topics. Worldwide ${ }^{4}$, it ranks the top 10 universities in two countries: United States (6) and England (4) (see Table 4). In the Latin American context, the top 10 places are in Brazil (4), Mexico (2), Chile (2), and Colombia (2) (see Table 5). Regarding Mexican universities, those that top the list are concentrated in the following states: Distrito Federal (5), Nuevo Leon (2), Puebla (1), Estado de Mexico (1), and Jalisco (1) (see Table 6);

(f) Academic Ranking of World Universities uses the following values: quality of teaching $(10 \%)$, quality of teachers $(40 \%)$, production research $(40 \%)$, and performance per capita $(10 \%)$. This ranking is occupied in its top 10 positions by eight American universities and two English ones. The first Latin American university to be mentioned is at number 146, this is the University of Sao Paulo. The first and only Mexican university considered in this list of 400 institutions is the Universidad Nacional Autónoma de México which ranks 217.

(2) Rankings reflect the inequality with which relationships among universities still occur. Although Mexico currently has 180 universities, in the case of national rankings, it is a small group of no more than 15 universities that always come out as the top 10 in 
Table 1. Webometrics World Best Universities

\begin{tabular}{lllllll}
\hline Ranking & University & Country & Presence & Impact & Opening & Excellence \\
\hline 1 & Harvard University & USA & 64 & 1 & 19 & 1 \\
2 & Massachusetts Institute of Technology (MIT) & USA & 7 & 1 & 57 & 13 \\
3 & Stanford University & USA & 11 & 4 & 11 & 2 \\
4 & University of California Berkeley & USA & 645 & 3 & 18 & 15 \\
5 & University of California Los Angeles (UCLA) & USA & 1,008 & 5 & 69 & 3 \\
6 & University of Washington & USA & 837 & 6 & 8 & 6 \\
7 & University of Michigan & USA & 23 & 11 & 21 & 5 \\
8 & Cornell University & USA & 639 & 7 & 10 & 22 \\
9 & University of Minnesota & USA & 909 & 8 & 23 & 20 \\
10 & University of Pennsylvania & USA & 13 & 14 & 67 & 9
\end{tabular}

Table 2. Webometrics Latin America Best Universities

\begin{tabular}{|c|c|c|c|c|c|c|c|}
\hline Ranking & $\begin{array}{l}\text { World } \\
\text { ranking }\end{array}$ & University & Country & Presence & Impact & Opening & Excellence \\
\hline 1 & 19 & Universidade de São Paulo (USP) & Brasil & 31 & 53 & 3 & 82 \\
\hline 2 & 36 & $\begin{array}{l}\text { Universidad Nacional Autónoma de } \\
\text { México }\end{array}$ & México & 33 & 59 & 6 & 275 \\
\hline 3 & 129 & $\begin{array}{l}\text { Universidade Federal do Rio } \\
\text { Grande do Sul (UFRGS) }\end{array}$ & Brasil & 63 & 342 & 8 & 445 \\
\hline 4 & 177 & $\begin{array}{l}\text { Universidade Estadual de Campinas } \\
\text { (UNICAMP) }\end{array}$ & Brasil & 1,458 & 253 & 12 & 314 \\
\hline 5 & 181 & Universidade de Brasília (UNB) & Brasil & 408 & 126 & 31 & 836 \\
\hline 6 & 205 & $\begin{array}{l}\text { Universidade Federal de Santa } \\
\text { Catarina (UFSC) }\end{array}$ & Brasil & 272 & 379 & 4 & 711 \\
\hline 7 & 221 & Universidad de Chile & Chile & 220 & 362 & 60 & 453 \\
\hline 8 & 223 & Universidad de Buenos Aires & Argentina & 619 & 248 & 134 & 368 \\
\hline 9 & 241 & $\begin{array}{l}\text { Universidade Federal do Rio de } \\
\text { Janeiro }\end{array}$ & Brasil & 353 & 479 & 43 & 381 \\
\hline 10 & 254 & $\begin{array}{l}\text { Universidade Federal de Minas } \\
\text { Gerais (UFMG) }\end{array}$ & Brasil & 475 & 512 & 14 & 478 \\
\hline
\end{tabular}

Table 3. Webometrics Mexico Best Universities

\begin{tabular}{|c|c|c|c|c|c|c|c|}
\hline Ranking & $\begin{array}{l}\text { World } \\
\text { ranking }\end{array}$ & University & State & Presence & Impact & Opening & Excellence \\
\hline 1 & 70 & $\begin{array}{l}\text { Universidad Nacional Autónoma de } \\
\text { México }\end{array}$ & $\begin{array}{l}\text { DF (Distrito } \\
\text { Federal) }\end{array}$ & 38 & 47 & 84 & 300 \\
\hline 2 & 591 & $\begin{array}{l}\text { Centro de Investigación y de } \\
\text { Estudios Avanzados (CINVESTAV) }\end{array}$ & DF & 2,397 & 787 & 1,208 & 568 \\
\hline 3 & 592 & $\begin{array}{l}\text { Universidad Autónoma } \\
\text { Metropolitana }\end{array}$ & $\mathrm{DF}$ & 926 & 514 & 467 & 1,042 \\
\hline 4 & 861 & Universidad de Guadalajara & Jalisco & 807 & 729 & 294 & 1,654 \\
\hline 5 & 950 & Tecnológico de Monterrey & Nuevo León & 947 & 950 & 579 & 1,570 \\
\hline 6 & 974 & Instituto Politécnico Nacional & DF & 817 & 1,548 & 410 & 931 \\
\hline 7 & 1,120 & $\begin{array}{l}\text { Universidad Autónoma del Estado } \\
\text { de México }\end{array}$ & Edo. México & 3,619 & 957 & 637 & 1,986 \\
\hline 8 & 1,327 & $\begin{array}{l}\text { Universidad Michoacana de San } \\
\text { Nicolás de Hidalgo }\end{array}$ & Michoacán & 1,210 & 1,865 & 837 & 1,438 \\
\hline 9 & 1,327 & Universidad de Sonora & Sonora & 2,145 & 1,096 & 474 & 2,369 \\
\hline 10 & 1,407 & $\begin{array}{l}\text { Universidad Autónoma de Nuevo } \\
\text { León }\end{array}$ & Nuevo León & 947 & 2,262 & 59 & 1,438 \\
\hline
\end{tabular}


Table 4. QS University World Best Universities

\begin{tabular}{llll}
\hline Ranking & University & Country & Score \\
\hline 1 & Massachusetts Institute of Technology (MIT) & USA & 100.00 \\
2 & University of Cambridge & Inglaterra & 99.78 \\
3 & Harvard University & USA & 99.15 \\
4 & University College London (UCL) & Inglaterra & 98.69 \\
5 & University of Oxford & Inglaterra & 98.57 \\
6 & Imperial College London & Inglaterra & 98.31 \\
7 & Yale University & USA & 97.48 \\
8 & University of Chicago & USA & 96.27 \\
9 & Princeton University & USA & 95.37 \\
10 & California Institute of Technology (Caltech) & USA & 95.05 \\
\hline
\end{tabular}

Table 5. QS University Latin American Best Universities

\begin{tabular}{|c|c|c|c|c|}
\hline Ranking & World ranking & University & Country & Score \\
\hline 1 & & Universidade de São Paulo (USP) & Brasil & 100.00 \\
\hline 2 & & Pontificia Universidad Católica de Chile & Chile & 99.20 \\
\hline 3 & & Universidade Estadual de Campinas & Brasil & 97.40 \\
\hline 4 & & Universidad de Los Andes Colombia & Colombia & 94.50 \\
\hline 5 & & Universidad de Chile & Chile & 93.50 \\
\hline 6 & & Universidad Nacional Autónoma de México (UNAM) & México & 93.10 \\
\hline 7 & & Tecnológico de Monterrey (ITESM) & México & 89.80 \\
\hline 8 & & Universidade Federal do Rio de Janeiro & Brasil & 89.20 \\
\hline 9 & & Universidad Nacional de Colombia & Colombia & 83.70 \\
\hline 10 & & Universidade Federal de Minas Gerais & Brasil & 83.10 \\
\hline
\end{tabular}

Table 6. QS University Mexico Best Universities

\begin{tabular}{lllll}
\hline Ranking & $\begin{array}{l}\text { Latin America } \\
\text { Ranking }\end{array}$ & University & State & Score \\
\hline 1 & 6 & Universidad Nacional Autónoma de México (UNAM) & DF & 93.10 \\
2 & 7 & Tecnológico de Monterrey (ITESM) & Nuevo León & 89.80 \\
3 & 16 & Instituto Politécnico Nacional (IPN) & DF & 78.60 \\
4 & 27 & Universidad Iberoamericana (UIA) & DF & 73.60 \\
5 & 31 & Instituto Tecnológico Autonomo de México (ITAM) & DF & 72.20 \\
6 & 33 & Universidad Autónoma Metropolitana (UAM) & DF & 70.50 \\
7 & 48 & Universidad de las Américas Puebla (UDLAP) & Puebla & 60.70 \\
8 & 60 & Universidad de Guadalajara (UDG) & Jalisco & 54.80 \\
9 & 61 & University Autónoma de Nuevo León (UANL) & Nuevo León & 54.50 \\
10 & 74 & Universidad Anahuac & Edo. De México & 89.80 \\
\hline
\end{tabular}

these lists. As mentioned before, these differences reflect structural differences in institutions rather than having elements for a fair or objective comparison of their performance. So for instance, institutions such as the Universidad Nacional Autónoma de México in 2014 had an annual budget of 35,584,146,143 pesos,
UAM in 2013 had a budget of 5,720,391,000 pesos (Universidad Autónoma Metropolitana [UAM] 2013), the UANL in 2014 had a budget of 6,366,561,000 pesos (Universidad Autónoma de Nuevo León [UANL] 2014). The Universidad Autónoma de Campeche in 2014 had a budget of $622,557,000$ pesos and the 
Universidad Autónoma de Aguascalientes had a budget in 2013 of 1,028,698,000 pesos (Universidad Autónoma de Aguascalientes [UAA] 2013);

(3) Rankings spatially reflect differences between network components of Mexican universities and the world. The spatial location of the universities does not follow a random pattern, but parallel power structures and complementary to the qualities that the organizations that are being rated by the power rankings have. Thus, the best university in the world are concentrated in developed countries, most notably in the United States, England, while in the case of Mexico the concentration occurs in three of the four states with the largest share of national gross domestic product (GDP) 2009: Distrito Federal (17.7\%), Nuevo León (7.5\%), and Jalisco (6.3\%). The Webometrics ranking includes a university in the Estado de Mexico which has a stake of $9.2 \%$ in gross domestic product (National Institute of Statistics and Geography [INEGI] 2009);

(4) The lists of universities are an account of the type of values held by the dominant institutions. International rankings use criteria, most of them accessible only for institutions with high budgets, allowing them, for example, to hire researchers with high international recognition and provide them facilities, staff, and time to devote their time exclusively to work such as research and publishing of articles. In most universities in countries like Mexico, university professors have a significant burden of class hours and do not have budgets assigned for research. Publication in internationally recognized journals does not fit into their list of priorities. The QS University Ranking includes criteria such as: number of papers published, citations, and awards. Phenomena such as asymmetric convergence between science and industry makes some international rankings to be interested in measuring the number of patents applied or projects that a university has. For their part, the Academic Ranking of World Universities uses the quality teacher criterion, composed by members of the institution who have received Nobel Prizes and Fields Medals and researchers with high citation index in various fields.

Usage of favorable criteria for large universities is also utilized in the case of Mexican rankings, for example, research or international prestige. The vast majority of universities in Mexico have as their main function the education of work frames set in the area covered by the state or city where they are located. Including criteria such as the above legitimates, the concentration in resources destined for certain institutions rather than helping to generate a measurement of the operation of each of these institutions.

\section{CONCLUSIONS}

The lists of the rankings analyzed are a sample that structural inequalities in society and universities, in particular, subsist; they reflect worldwide how the most powerful economic powers (the United States in first place and England in eighth place but still one of the countries with universities of the greatest tradition) ${ }^{5}$ account for the privileged places in these listings. At a Latin American and national level, the panorama is very similar; countries and cities whose universities are at the top are also the best positioned in terms of its GDP according to the data provided by the Inter-American Development Bank (IDB) in the international setting and the National Institute of Statistics and Geography (INEGI) for the Mexican case.

The construction of rankings is not due to an "objective" or procedure that seeks to create knowledge on the status of the universities, but rather, they are part of a vision (program) on the purpose and development of such social institutions that are generated from hubs of information and that mostly responds to the global aim of promoting uniform values for marketing purposes. Activities carried out from these hubs (new programs, advances in the 
internet, etc.) are considered as fundamental to measure a "good" performance of a university, ruling out other measures where universities with a social or cultural impact could get high scores.

The simple fact that this type of measurement exists tells us about the reconfiguration of power, as this type of classifications that are made from the hubs (in power), set the tone for what is deemed relevant, that which is valuable and therefore worth giving it a rating that also presents itself as "objective". The new codes of the network society validate the behaviors and criteria that will dictate what makes a university successful or not, (and these have not changed, they have only added new), that which is evaluated becomes important, in the case the Webometrics ranking the mere fact of not having presence on the internet determines that the institution is "invisible" and not even considered and the consequences that entails in the network that universities make because the strong media impact generated by these measurements is a reality.

This type of international benchmarks is an example of the differences among universities, not only do they continue but they become institutionalized with universal criteria that are not based on indicators and values generated in our social, economic, academic, and cultural contexts and circumstances and thus, add themselves to processes that encourage and/or justify situations of inequality and social exclusion that are rooted in what society "assumes", "normalizes", and therefore stops questioning.

\section{Funding}

The study was supported by research funds from the Sonora State University through the research group "Innovation and Educational Development".

\section{Notes}

1. Presidencia de la República. 2013. Plan Nacional de desarrollo 2013-2018. Retrieved (http://pnd.gob.mx/wpcontent/uploads/2013/05/PND.pdf).

2. Castells understood power as relational capability that allows an actor asymmetrically influence the decisions of other(s) player(s) so as to promote the desires, interests, and values of the empowered actor (Castells 2009: 10).

3. It is ancybermetrics laboratoryinitiative, which belongs to the Superior Council for Scientific Research (CSIC).

4. For more information, please visit the site. Retrieved (http://www. topuniversities.com).

5. Inter-American Development Bank (IDB) data can be found on the website. Retrieved (http://www.indexmundi. $\mathrm{com} / \mathrm{g} / \mathrm{r}$.aspx $? \mathrm{t}=50 \& \mathrm{v}=65 \& \mathrm{l}=\mathrm{es})$.

\section{References}

Academic Ranking of World Universities. 2014. Internet Site. Retrieved (http://www.shanghairanking.com/es/ARWU 2014.html).

Acosta Silva, A. 2000. Estado, politicas y universidades en un periodo de transición (State, Policy and Universities in a Transition Period). México: Fondo de Cultura Económica.

América Económica. 2015. Ranking 2015 Universidades de México (Ranking Universities of Mexico 2015). Retrieved (http://rankings.americaeconomia.com/mejores-universidad es-mexico-2015/metodologia/).

Brunner, J. J. 2007. "La universidad latinoamericana frente al próximo milenio" (Latin American Universities Facing the Next Millennium). Pp. 217-231 in Antología del pensamiento latinoamericano sobre la educación, la cultura y las universidades (Anthology of Latin American Thinking on Education, Culture and Universities). México: UNAM.

Castells, M. 2004. The Network Society: A Cross-Cultural Perspective. Vol. 1. United Kingdom: Edward Elgar Publishing Limited.

. 2009. Comunicación y poder (Communication and Power). Madrid: Alianza Editorial.

- 2010. The Rise of the Networ Society. USA: Wiley-Blacwell.

Clark, C. 2002. "El futuro de la Educación Superior" (The Future of Higher Education). Perfiles Educativos (Educational Profiles) 24(96):97-103.

De Sousa Santos, B. 2006. La universidad popular del siglo XXI (The Popular University of the XXI Century). Perú: Fondo Editorial de la Facultad de Ciencias Sociales.

Docampo, D. 2008. "Rankings internacionales y la calidad de los sistemas universitarios" (International Rankings and the Quality of University Systems). Revista de educación (Journal of Education) Special Issue:146-179. 
Dubet, F. 2004. La escuela de las oportunidades (School Opportunities). España: Gedisa.

El Financiero. 2014. Las mejores universidades de México (The Best Universities in Mexico). Retrieved (http://eleconomista. com.mx/especiales/americaeconomia/2014/06/19/las-mejor es-universidades-mexico-ranking-2014).

Forbes. 2015. Las diez mejores universidades en Latinoamérica (The Ten Best Universities in Latin America). Retrieved (http://www.forbes.com.mx/las-10-mejores-universidades-d e-america-latina/).

INEGI (National Institute of Statistics and Geography). 2009. Contribution to the Gross Domestic Product (GDP). Retrieved (http://cuentame.inegi.org.mx/monografias/ informacion/mex/economia/pib.aspx?tema).

Kleinman, D. and S. Vallas. 2011. "Contradiction in Convergence: Universities and Industry in the Biotechnology Field." Pp. 35-62 in The New Political Sociology of Science. USA: University of Winsconsin Press.

Martínez Rizo, F. 2011. "Los rankings de universidades: una visión crítica" (University Rankings: A Critical View). Revista de la educación superior (Journal of Higher Education) 40(157):77-97.

Ornelas, C. 2008. Politics, Power and Desks. Criticism of the New Educational Federalism. México: Siglo XXI.

Tuirán, R. 2012. La educación Superior en México 2006-2012: Un balance inicial (Higher Education in Mexico 2006-2012: An Initial Balance). México: Observatorio Académico.

UNESCO (United Nations Educational, Scientific, and Cultural Organization). 2005. Towards Knowledge Societies. Paris: UNESCO.

Universidad Autónoma de Aguascalientes (UAA). 2013. Presupuesto de ingresos para el ejercicio del 1 de enero al
31 de diciembre de 2013 (Budget: January 1 to December 31, 2013). Retrieved (http://www.uaa.mx/ transparencia/).

Universidad Autónoma de Campeche (UAC). 2014. Programa Operativo Anual 2014 (Annual Operating Program 2014). Retrieved (http://etzna.uacam.mx/transparencia/VII/2014/ POA\%202014.pdf).

Universidad Autónoma de Nuevo León (UANL). 2014. Presupuesto de ingresos y egresos (Budget Revenues and Expenditures). Retrieved (http://transparencia.uanl.mx/ informacion_presupuestal/presupuesto_2014/archivos/Pres upuesto_2014.pdf).

Universidad Autónoma Metropolitana (UAM). 2013. Presupuesto de ingresos y egresos (Budget Revenues and Expenditures). Retrieved (http://www.uam.mx/trans parencia/presupuesto/presup2013/presupuesto2013-12Dic2 012.pdf).

Webster, D. S. 1986. Academic Quality Rankings of American Colleges and Universities. Springfield, I.L.: Charles C. Thomas Publ.

Webster, F. 1995. Theories of the Information Society. USA: Routledge.

\section{Bios}

Mario Alberto Velázquez García, Ph.D., professor, Instituto Tecnológico Superior de Cajeme (Higher Technological Institute of Cajeme), México; research fields: education, public policy, tourism, and social movements.

Lilián Ivetthe Salado Rodríguez, Mg., professor, Universidad Estatal de Sonora (Sonora State University), México; research fields: higher education institutions, educational technology, educational policy, and digital divide. 